Vladimir Mićić ${ }^{1}$

Faculty of Economics, University of Kragujevac

Ljubodrag Savić ${ }^{2}$

Faculty of Economics, Belgrade University
ORIGINAL SCIENTIFIC ARTICLE doi:10.5937/ekonomika1804045M

Received: October, 18, 2018 Accepted: November, 05, 2018

\title{
SUSTAINABLE DEVELOPMENT OF THE SERBIAN MANUFACTURING INDUSTRY ${ }^{3}$
}

\begin{abstract}
Structural changes are crucial for sustainable industrial development. The aim of the paper is to point out that structural changes in the Serbian manufacturing industry should be accompanied by growth in production specialization and the share of hightechnology products in order to increase competitiveness. For the analysis of structural changes, a comparative method is used, to analyze production specialization, industrial sector specialization index, and for the analysis of competitiveness, the revealed comparative advantage index. The manufacturing industry is the most important sector of the Serbian economy, and, despite growth, specialization in this field is not high, which affects the lack of comparative advantages and uncompetitiveness of this sector on the EU market. The paper can be of assistance to industrial policy makers, in order to determine the best path to sustainable industrial development, using the benefits of production specialization.
\end{abstract}

Key words: structural changes, specialization, competitiveness, sustainable development

JEL classification: L16, O14, Q01

\section{ОДРЖИВИ РАЗВОЈ СРПСКЕ ПРЕРАЪИВАЧКЕ ИНДУСТРИЈЕ}

\begin{abstract}
Апстракт
Структурне промене су кључне за одрживи индустријски развој. Циљ рада је да укаже да би структурне промене српске прерађивачке индустрије требале да буду праћене растом производне спеичјализащије и учешћа производа са највишим нивоом технолошке интензивности, како би дошло до раста конкурентности. За потребе анализе структурних промена користи се компаративни метод, за анализу производне специјализащије индекс специјализаџије индустријског сектора, а за анализу конкурентности индекс откривених компаративних предности. Прерађивачка индустрија је најважнији сектор економије Србије

\footnotetext{
${ }^{1}$ micicv@kg.ac.rs

${ }^{2}$ ljubas@ekof.bg.ac.rs

${ }^{3}$ This paper is the result of research on the Project No. 179065 which is funded by the Ministry of Education, Science, and Technological Development of the Republic of Serbia.
} 
у коме и поред раста специјализачија није висока, ито утиче да овај сектор не остварује компаративне предности и није конкурентан на тржишту ЕУ. Рад је може бити од помоћи креаторима индустријске политике, како би се одредио најбољи пут ка одрживом индустријском развоју, користећи предности производне специјализащије.

Кључне речи: структурне промене, специјализација, конкурентност, одрживи развој

\section{Introduction}

Sustainable industrial development emphasizes the role of industrialization as a long-term driver of development, and encompasses inclusion, improvement of competitiveness, and environmental protection (UNIDO, 2015, p. 8). Sustainable industrial development requires structural changes, i.e. the ability to continuously generate new, more dynamic activities with higher productivity and, therefore, competitiveness. The perspective of structural change often emphasizes desirability and control of the direction of change.

To control the direction of structural change, industrial policy is very important, the one that includes any type of intervention seeking to improve the business environment or to change the structure of economic activity towards industries and technologies that are expected to provide better growth prospects than would occur in the absence of such an intervention (Warwick 2013, p. 14). Industrial policy is also important for the growth of production and export specialization in the manufacturing industry (Boeheim, Michael, et al., 2005, p. 6.) The manufacturing industry has been a driver of economic development in developing countries (Szirmai, 2012, p. 417), and, today, the role of this sector does not decrease, but rather increases (Haraguchi, Cheng \& Smeets, 2017, p. 293).

Industrial development is accompanied by changes in economic activities both between and within sectors, which determines specialization and competitiveness (Romano \& Traù, 2017, p. 35). The growth of production and export specialization of the manufacturing industry in developing countries leads to productivity and competitiveness growth and their ability to compete on the global market. For small developing economies, as in the case of Serbia, competitiveness of the manufacturing industry is essential for sustainable economic development.

Therefore, the research subject in this paper is the connection between structural changes in the manufacturing industry production specialization of Serbia and the new EU member states, especially in conditions when the EU's industrial policy focuses on digitization and development of new industries in the future. The aim of the paper is to show that structural changes of the Serbian manufacturing industry should be accompanied by growth in production specialization and the share of high-technology products in order to increase its competitiveness.

The starting hypothesis in the paper is that there is a connection between structural changes, production specialization, and competitiveness of the manufacturing industry of Serbia and new EU member states. In addition to Serbia, the EU member states will 
be analyzed, with special emphasis on new members from Central and Eastern Europe (CEE), having representative manufacturing sector within the respective economies and being similar in size.

\section{Theoretical background}

Economic theory states that the structure of the manufacturing industry is very important for developing countries' economic development, as some activities have a higher level of productivity and growth rates, and especially because the products of this sector represent a significant part of export. It is also underlined that economic development is more successful if it is narrower production specialization and export (UNIDO, 2015, p.77). Experience shows that production specialization in small economies is an important factor of structural change and a strategy for sustainable economic development (Foster-McGregor, Kaba \& Szirmai, 2015, p. 2). Production specialization is accompanied by export specialization, and export plays an important role in promoting economic development of small economies (Krugman, Obstfeld \& Melitz 2012, pp. 40). Changes in the level of specialization give data on the potential, volatility, and length of growth, level and growth of productivity, competitiveness, and export. Countries specialize, vertically or horizontally, on the basis of comparative advantages, available factors and resources, labour costs and productivity (Aiginger \& Rossi-Hansberg, 2006, pp. 255-266).

Economic theorists have no single opinion on the place and role of production specialization (Mićić, Savić, \& Radičić, 2018, p. 82). On the one hand, it is considered that specialization increases productivity, competitiveness, and export, and, on the other hand, that diversification and a wider range of production activities provide more opportunities and make the manufacturing industry more capable of using the effects of technological innovation, networking, and spillover of labour productivity growth from this sector into other sectors. Also, countries with a high level of specialization are less capable of sustaining growth in the long run, and, in some cases, to deal with external shocks successfully. Therefore, it is emphasized that at lower levels of GDP per capita diversification reduces instability and makes economic growth higher and longlasting. Countries with high GDP per capita have more benefits from specialization.

The diversity of results exists in empirical research as well (Russ, 2015, pp. 63-73; UNIDO, 2015, pp. 28-29, Kaulich, 2012; Imbs \& Wacziarg, 2003, pp. 63-86). Studies examine the existence of a positive link between the level of production specialization and the level of GDP per capita. They analyze whether the ratio takes the form of the letters $U$ or L. Some studies show the existence of the curve U for production, some for export, and some show that diversification continues at a high level of GDP per capita. In different countries, other than those in which the manufacturing industry is highly sophisticated, industrial development requires specialization and concentration (Hausmann \& Rodrik, 2003, p. 610).

Research on production specialization in EU member states, especially new ones, shows its growth, that the level of specialization and the size of the manufacturing industry are not linked, that smaller countries have a higher level of specialization, and vice versa. Research shows that EU members whose industrial policy is focused 
on creating a more diversified production structure and productive production activities achieve better economic performance and a higher level of competitiveness (Russ, 2015; Mićić, Savić \& Radičić, 2018, pp. 88-90).

Today, the EU is primarily focused on sustainable production and employment growth, and, with that in mind, it seeks to exploit the opportunities of globalization and digitization in order to achieve faster productivity and competitiveness growth. Therefore, it encourages technological innovation and controls structural changes through different policies and the involvement of stakeholders in strategic partnerships (Bachtler, 2017, p. 1). Digital and other advanced technology influences the EU's application of industrial policy measures in order to fully utilize the possibilities of digitization, which is crucial for the growth of competitiveness of the manufacturing industry.

Under conditions of the knowledge economy in the EU, smart production specialization is also gaining in importance, which stimulates and accelerates structural changes in the manufacturing industry and affects its productivity growth. It is a concept that deals with vertical intervention and selection of preferred production activities that will receive priority and be favored, through concentration of resources. Smart specialization is based on the implementation of smart state policies, i.e. innovative, industrial, and educational policies (Foray, 2013, pp. 1-15). Thus, smart production specialization represents a strategic approach to the economic development of the EU through targeted support and investment in knowledge, research, technological development, and key industrial priorities (Clar, 2015, p. 1291). This concept of production specialization is particularly important for the development of Industry 4.0, which provides important opportunities for developing countries to move towards inclusive and sustainable industrial development faster (UNIDO, 2017, p. 2).

The growth of competitiveness of the manufacturing industry is putting pressure on innovation, in particular using Industry 4.0-related technology. It promotes integration into global value chains, affects productivity growth, and increases efficiency of energy and resource use. It is particularly important for the growth of competitiveness of developing countries and fast-growing economies that fall into the middle income "trap" (UNIDO, 2017, p. 34). The failure of transition to knowledge and innovation leads them to deindustrialization. Engaging in global value chains by increasing the speed of technological change and new innovation puts pressure on middle-income countries to improve their productive capacity. Pressure will be even greater since digitization leads to reorientation of global production and trade to developed countries (Bachtler, 2017, p. 49).

The growth of production and export specialization in the manufacturing industry of developing countries leads to productivity growth and their ability to compete on the international market in the export of similar industry products from other countries. For small manufacturing industries, export competitiveness is essential for the promotion of sustainable economic growth and development and survival in the global economy (UNIDO, 2017, p. 4). The competitiveness of the manufacturing industry is its ability to produce and export competitive products. It directly affects its production and export capacity, which then affects the total and per capita value added. An important aspect is the level of technological development and the quality of export, which depend on the intensity of industrialization and structural changes (UNIDO, 2017, p. 36).

It is important to point out that the competitiveness of the manufacturing industry covers a large number of factors, from production costs, through technological 
innovation, product quality and differentiation, exchange rates, to non-price factors of structural competitiveness. A comparative advantage is used to determine the patterns and trends of production and export specialization, as well as where one country achieves competitiveness. It is a fact that countries differ in terms of labor productivity in different industries, producing and exporting products in which they are relatively more productive and more efficient (Krugman et al. 2012, pp. 40-48). It is also certain that it is very difficult to precisely measure competitiveness due to the lack of data on the costs of factors affecting it (Balassa, 1965, p. 99).

\section{Methodology and hypotheses}

In this paper, a comparative method will be used to show the trends of structural changes in Serbia and selected EU members, by years in the period 2010-2017. The trends relate to the share of the manufacturing industry in the creation of total value added, as well as on production and export of high-tech products. This method will also show a trend in the specialization and competitiveness of the manufacturing industry.

The method of quantitative analysis will be used to measure the relative sector specialization of the manufacturing industry. The research uses a number of indicators of relative production specialization (Palan, 2010, p. 1, Saboniene, 2009, p. 51, Aiginger, 2000, p. 84, Balassa, 1965, p. 99). Even though there are some limitations (European Commission, DGEI, 2011, p.106), to analyze production specialization of the manufacturing industry, the industrial sector specialization index $\mathrm{S}$ will be used in this paper. It is calculated as follows:

$$
S_{i, j}=\frac{\frac{G V A_{i, j}}{\sum_{j} G V A_{i, j}}}{\frac{G V A_{E U, j}}{\sum_{j} G V A_{E U, j}}}
$$

Where: $S_{\mathrm{i}, \mathrm{j}}$ - industrial sector specialization index, GVA - gross value added; i country, $\mathrm{j}$ - manufacturing sector.

The specialization index compares the share of the GVA of the manufacturing industry in the total GVA of the observed economy with the share of GVA of EU industry in the total GVA of the EU economy. Value of 1 for the manufacturing industry shows the same share in that sector in the observed country and the EU. When the index value is above (below) 1 , it indicates specialization (no specialization) of the observed country. The higher indicator value means the higher level of specialization of the manufacturing industry in relation to the EU average.

Starting from the relative production specialization within the quantitative analysis, the revealed comparative advantage (RCA) index of the manufacturing industry will also be used. It shows the comparative advantages and export performance of a particular activity, is known as the Balassa index, and is defined using the data on export and import (Balassa, 965, p. 99). In this paper, one of the RCA index modifications will be used, which is calculated as follows:

$$
R C A \log _{10}=\frac{\frac{X_{i, j}}{X_{i, E U}}}{\sum X_{j}}
$$


Where RCA - revealed comparative advantage index, $X_{i, j}$ - manufacturing industry export of country $\mathrm{j}, \mathrm{X}_{\mathrm{i}, \mathrm{EU}}$ - manufacturing industry export of the $\mathrm{EU}, \mathrm{X}_{\mathrm{j}}$ - total export of country $\mathrm{j}$, and $\mathrm{X}_{\mathrm{EU}}$ - total EU export.

The positive value and level of RCA indicate the level of comparative advantage of the manufacturing industry of the observed country, while the negative values of RCA indicate disadvantages. The intensity of changes in the RCA index by one in the logarithmic scale indicates a tenfold increase in competitiveness and export in relation to the observed export market.

The paper should confirm the hypothesis on the connection between structural changes, production specialization, and competitiveness of the manufacturing industry of Serbia and new EU member states. In order to verify the hypothesis, the following auxiliary hypotheses will be tested:

H1: Production specialization in the Serbian manufacturing industry and EU member states from CEE is above the EU average.

$\mathrm{H} 2$ : The manufacturing sector of EU members from the CEE region has comparative advantages.

H3: The growth of production specialization of the EU's manufacturing industries in the CEE is accompanied by the growth of comparative advantages.

The survey uses the Eurostat data. The scope of the manufacturing sector is defined according to the NACE classification, while the analysis of export of this sector is at the highest level of data aggregation of the Standard International Trade Classification (Revision 4) and includes groups 5 to 8 .

\section{Discussion of research results}

The share of the manufacturing industry of Serbia of $18.5 \%$ in the creation of the total GVA in 2017 is above the EU-28 average (16.5\%). In some CEE members, the share is over $20 \%$ (Graph 1).

Graph 1. Gross value added of the manufacturing sector

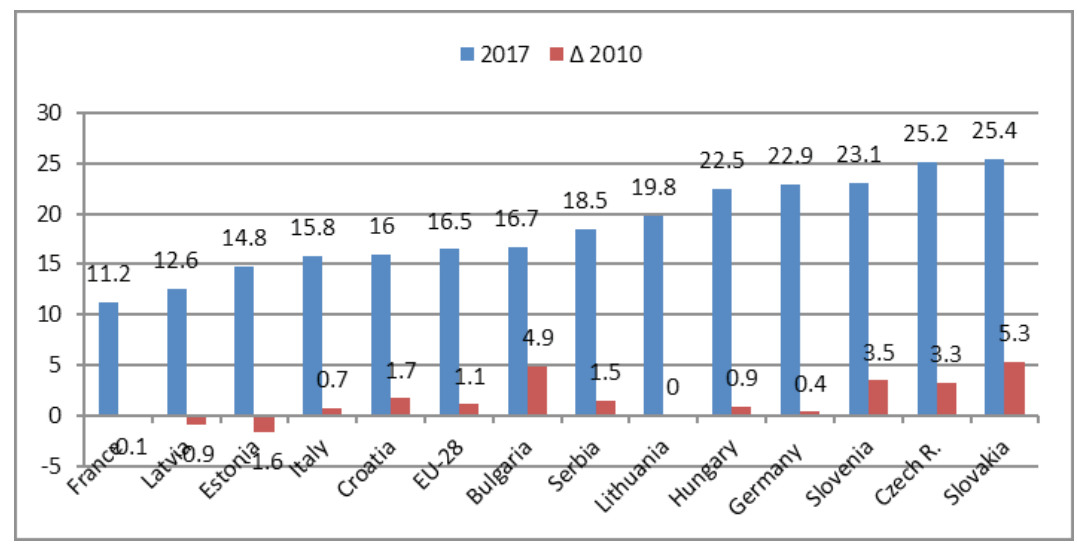

Source: Authors' calculation based on Eurostat data 
The process of transition, as well as the effects of economic crisis and recession, have led to a change in the significance and relative role of this sector. Deindustrialization is characteristic of old and developed EU members, but also the CEE transition economies. Nevertheless, most member countries record slowdown in decline and growing share of this sector, and the EU is striving to build a strong industrial base because a strong industry plays an important role in innovation, productivity growth, competitiveness, and sustainability of the EU economy growth. For this purpose, members are pursuing an industrial policy that encourages investment in the development of smart, technologically innovative, competitive, and sustainable industries. It is predominantly horizontal, but partly also vertical industrial policy, which is to accelerate structural changes, develop a business environment suitable for industry development. The manufacturing sector in Serbia recorded growth of 1.5 percentage points in 2017 compared to 2010, which is good considering that, in the longer term, it also faced decline in the share of GVA as a result of inefficient structural changes. Growth is the result of the inflow of foreign capital and increased investment activity.

Table 1 shows the values and changes in the value of the manufacturing sector $\mathrm{S}$ index in the period 2010-2017. The calculated values of the $\mathrm{S}$ index are higher in most of the observed CEE countries compared to the EU-28 average, while Latvia, Estonia, and Croatia record the lack of specialization in the manufacturing industry. The manufacturing sector of Serbia records the S index value slightly above one, which is above the EU-28 average, but below the level of the new CEE member countries observed. This, except for Latvia, Estonia, and Croatia, confirms an auxiliary H1. This deviates from the usual practice that small economies have a higher degree of specialization. The change of specialization points to growth of specialization of the EU member states' manufacturing sector, in accordance with their comparative advantages and efforts to implement strategic documents and defined directions of development and industrial policy. In Serbia, the level of specialization in the manufacturing sector is not at a sufficiently high level compared to its industrial development phase, as confirmed by previous research (Mićić, Savić \& Radičić, 2018, p. 88).

Table 1. Industrial sector specialization index

\begin{tabular}{|l|c|c|c|c|c|c|c|c|c|}
\hline & 2010 & 2011 & 2012 & 2013 & 2014 & 2015 & 2016 & 2017 & $\Delta 2010$ \\
\hline EU 28 & 1,00 & 1,00 & 1,00 & 1,00 & 1,00 & 1,00 & 1,00 & 1,00 & 0,00 \\
\hline Czech R. & 1,42 & 1,56 & 1,58 & 1,58 & 1,67 & 1,56 & 1,56 & 1,53 & 0,11 \\
\hline Hungary & 1,40 & 1,43 & 1,40 & 1,42 & 1,45 & 1,50 & 1,40 & 1,36 & $-0,04$ \\
\hline Slovakia & 1,31 & 1,38 & 1,54 & 1,65 & 1,62 & 1,59 & 1,59 & 1,54 & 0,23 \\
\hline Slovenia & 1,27 & 1,27 & 1,35 & 1,41 & 1,48 & 1,38 & 1,38 & 1,40 & 0,13 \\
\hline Estonia & 1,06 & 1,01 & 1,01 & 0,97 & 1,01 & 0,92 & 0,91 & 0,90 & $-0,17$ \\
\hline Latvia & 0,88 & 0,84 & 0,83 & 0,82 & 0,77 & 0,72 & 0,75 & 0,76 & $-0,11$ \\
\hline Lithuania & 1,29 & 1,31 & 1,40 & 1,29 & 1,27 & 1,21 & 1,15 & 1,20 & $-0,09$ \\
\hline Bulgaria & 0,77 & 0,81 & 0,90 & 0,82 & 0,87 & 0,89 & 0,85 & 1,01 & 0,25 \\
\hline Croatia & 0,93 & 0,94 & 0,97 & 0,95 & 0,99 & 0,99 & 1,01 & 0,97 & 0,04 \\
\hline Serbia & 1,10 & 1,12 & 1,24 & 1,22 & 1,19 & 1,10 & 1,11 & 1,12 & 0,02 \\
\hline
\end{tabular}

Source: Authors'calculation based on Eurostat data

The big disadvantage is the fact that, at the time of Industry 4.0 development in the Serbian manufacturing industry, Production of computers, electronic, and optical 
products and Production of pharmaceutical products, as high-tech areas with the highest level of productivity and the creation of GVA participate with less than $1 \%$ and are twice lower than the EU-28 average (Graph 2). The largest share of propulsive high technology areas is in the manufacturing sectors of Slovakia, the Czech Republic, and Slovenia, which have the highest value of production specialization.

Graph 2. Gross value added of high-tech areas in the manufacturing sector, in \%

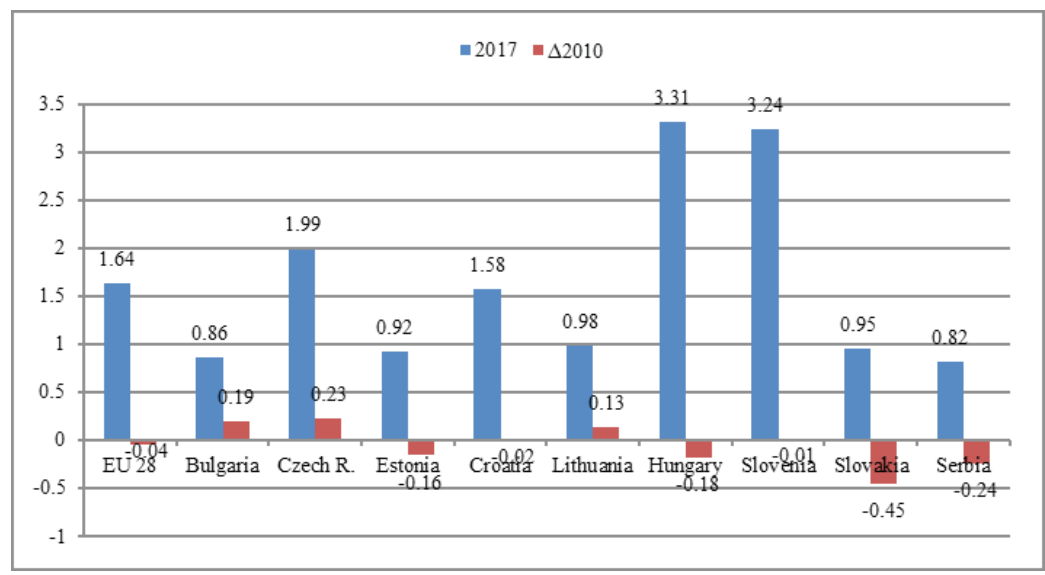

Source: Authors'calculation based on Eurostat data

Negative values of RCA for the Serbian manufacturing sector show uncompetitiveness on the EU market. Positive values of RCA index show that the manufacturing industries of the CEE countries have comparative advantages, thus confirming the auxiliary $\mathrm{H} 2$. The growth of RCA since 2010 shows rise, and decline fall in the competitive position. The highest level of competitiveness is in the manufacturing industry of the Czech Republic, Slovakia, Slovenia, and Hungary, and the lowest level in Croatia and Bulgaria. In addition to these two countries, all other CEE countries observed show a relatively stable trend of growth and insignificant RCA oscillations, in line with changes in levels and growth of specialization in this sector in the observed EU member states, which confirms the auxiliary H3.

Table 2. RCA

\begin{tabular}{|l|c|c|c|c|c|c|c|c|c|}
\hline & 2010 & 2011 & 2012 & 2013 & 2014 & 2015 & 2016 & 2017 & $\Delta 2010$ \\
\hline Bulgaria & 0,35 & 0,48 & 0,48 & 0,41 & 0,41 & 0,54 & 0,45 & 0,45 & 0,09 \\
\hline Czech R. & 0,66 & 0,69 & 0,70 & 0,70 & 0,72 & 0,72 & 0,73 & 0,73 & 0,06 \\
\hline Estonia & 0,48 & 0,37 & 0,37 & 0,37 & 0,37 & 0,54 & 0,43 & 0,30 & $-0,18$ \\
\hline Croatia & 0,30 & 0,30 & 0,30 & 0,30 & 0,22 & 0,37 & 0,43 & 0,30 & 0,00 \\
\hline Latvia & 0,30 & 0,40 & 0,40 & 0,48 & 0,48 & 0,48 & 0,48 & 0,40 & 0,10 \\
\hline Lithuania & 0,24 & 0,35 & 0,30 & 0,34 & 0,38 & 0,48 & 0,48 & 0,38 & 0,14 \\
\hline Hungary & 0,61 & 0,61 & 0,64 & 0,65 & 0,66 & 0,67 & 0,64 & 0,65 & 0,04 \\
\hline Slovenia & 0,62 & 0,62 & 0,60 & 0,62 & 0,64 & 0,64 & 0,66 & 0,68 & 0,06 \\
\hline Slovakia & 0,67 & 0,66 & 0,65 & 0,67 & 0,66 & 0,70 & 0,66 & 0,65 & $-0,02$ \\
\hline Serbia & $-0,07$ & $-0,07$ & $-0,07$ & $-0,07$ & $-0,07$ & $-0,07$ & $-0,25$ & $-0,22$ & $-0,18$ \\
\hline
\end{tabular}

Source: Authors'calculation based on Eurostat data 
Table 2 shows values and changes in the value of RCA. The negative values of RCA in the manufacturing sector of Serbia are the consequence of the fact that Serbia is not a member of the EU, that the integration of CEE countries has affected production and trade convergence, which makes it difficult to export to this market due to numerous limitations, but it is even more important that the Serbian manufacturing industry does not have high production and export of technologically intensive products in order to be more competitive in relation to CEE member countries on this market.

The level of competitiveness and export potential is also shown by the relative ratio of RCA of the two industries in the same year. The EU CEE countries with similar RCA have a higher potential for mutual and intra-industrial trade. Relative RCA ratio in two consecutive years shows a change in the manufacturing industry competitiveness of the observed country. Those with RCA growth throughout the period are changing not only in quantitative terms, but also in qualitative terms, and knowledge and innovation in these countries are increasingly becoming competitiveness factors.

Graph 3 shows the share of export of high-tech products in the total export of the manufacturing industry. In the Serbian export structure, high-tech products account for less than $2 \%$ and record a decline in share in the period 2010-2017.

Graph 3. Export of high-tech products, in \%.

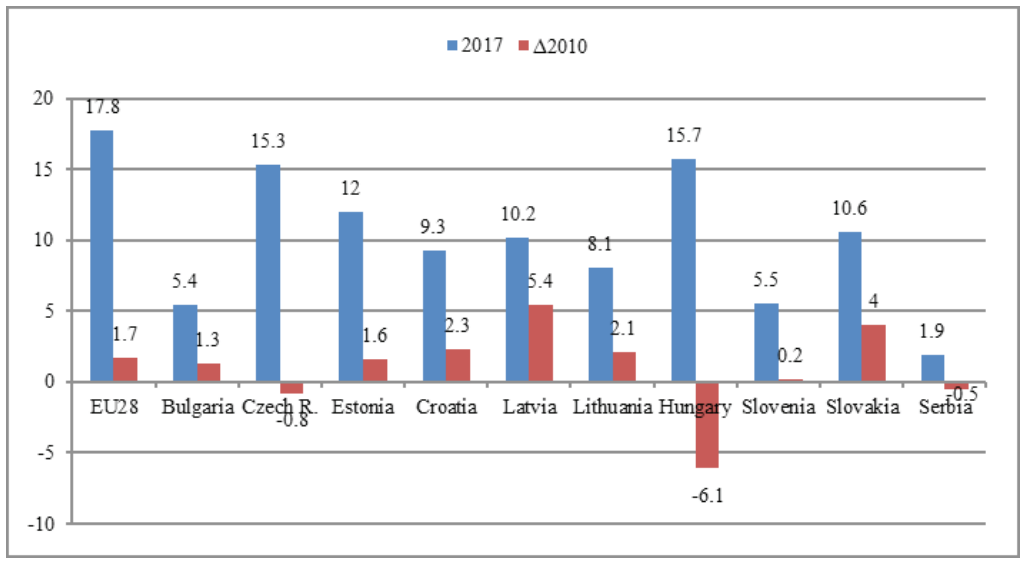

Source: Authors'calculation based on Eurostat data

This is significantly less than the EU-28 average and points to the unfavorable structure, but also the volume of export in relation to EU members from the CEE, especially compared to the Czech Republic, Slovakia, and Hungary, which in the observed period (except Hungary) record a constant increase in the share of high-tech products in total export. With this high share of high-tech products in the Serbian manufacturing industry it is difficult to compete with the observed CEE countries on the world as well as on the EU market.

\section{Conclusion}

The manufacturing industry is an important part of the Serbian and CEE economies, which is confirmed in its share in the total GVA. After the economic crisis and recession, most 
CEE members slowed down their fall or recorded growth in the sector's share in total GVA. The EU is striving to build a strong industrial base that plays an important role in the sustainable growth and development of the EU economy. With this in mind, the EU is implementing an industrial policy that encourages investment in the development of Industry 4.0

As a result of the increased investment activity, the manufacturing sector in Serbia records rise in its share in GVA, which is good considering that it faced intensive decline in the long run. However, the analysis also shows that, at the time when the EU encourages the development of Industry 4.0, in Serbian manufacturing sector, high-tech products account for less than 1\%, twice lower than the EU average, which reflects on its competitiveness and export, so the share of high-technology products in export is below $2 \%$.

The manufacturing industry in the observed CEE countries, with the exception of Latvia, Estonia, and Croatia, records specialization above the EU average. The manufacturing sector of Serbia records production specialization above the EU average, but below the level of other CEE member countries observed. This partly confirms auxiliary H1. Positive values of RCA index show that the manufacturing industries of the CEE countries have comparative advantages, thus confirming the auxiliary H2. Negative values of the Serbian manufacturing sector show uncompetitiveness on the EU market. Countries with growing RCA record growing competitiveness, and vice versa, in line with changes in levels and growth of specialization of this sector in the observed EU member states from the CEE, which confirms the auxiliary $\mathrm{H} 3$. This practically confirms the hypothesis that there is a connection between structural changes, production specialization, and competitiveness of the manufacturing industry of Serbia and most of the new CEE member states.

The manufacturing industry is the most important sector of the Serbian economy, which, despite growth, does not record high specialization, which affects uncompetitiveness of this sector on the EU market. Therefore, further research may focus on the correlation of factors that affect competitiveness with the direction of change in the production structure. The paper can be of assistance to industrial policy makers, in order to determine the best path to sustainable industrial development, using the benefits of production specialization. The fact is that production specialization is the basis for export specialization, so the solution is to change the production orientation towards production digitization and Industry 4.0 development.

\section{References}

Aiginger, K. (2000). Specialisation of European manufacturing. Austrian Economic Quarterly, 2(2000). 82-92.

Aiginger, K., \& Rossi-Hansberg, E. (2006). Specialization and concentration: a note on theory and evidence. Empirica, 33(4). 255-266.

Bachtler, J. (2017). Towards cohesion Policy 4.0: Structural transformation and inclusive growth. Regional Studies Association, RSA Europe. 1-46.

Balassa, B. (1965). Trade Liberalisation and Revealed Comparative Advantage, The Manchester School of Economic, Vol. 33, Issue 2. 99-123. /doi: 10.1111/j.14679957.1965.tb00050.x/abstract.

Boeheim, M., Handler, H., Ketels, C., Palmberg, C., \& Török, Á. (2005). Towards a renewed industrial policy in Europe. 
European Commission,(2011). EU industrial structure 2011 — Trends and Performance. Office of the European Union, Luxembourg, doi:10.2769/28487

Eurostat. (30. August 2018). Statistical databases. Retrieved. 30. August 2018, from http://ec.europa.eu/eurostat/data/database.

Foray, D. (2013). Smart specialisation and the New Industrial Policy agenda. Policy Brief, (8), 1-15.

Foster-McGregor, N., Kaba, I., \& Szirmai, A. (2015). Structural change and the ability to sustain growth. Inclusive and Sustainable Industrial Development Working Paper Series, Viena, 19.

Haraguchi, N., Cheng, C. F. C., \& Smeets, E. (2017). The importance of manufacturing in economic development: Has this changed? World Development, 93, 293-315.

Hausmann, R., \& Rodrik, D. (2003). Economic development as self-discovery. Journal of development Economics, 72(2). 603-633.

Imbs, J., \& Wacziarg, R. (2003). Stages of diversification. The American Economic Review, 93(1), 63-86.

Krugman, P., Obstfeld, M., \& Melitz M., (2012). International Economics-Theory and Policy. New York: Addison Wesley.

McCann, P., \& Ortega-Argilés, R. (2015). Smart specialization, regional growth and applications to European Union cohesion policy. Regional Studies, 49(8). 1291-1302.

Mićić, V., Savić, L., \& Radičić, D. (2018). The level of production specialization: Serbia and the new EU member states. Industrija, 46(1), 79-95. doi: 10.5937/ industrija46-1559.

Romano, L., \& Traù, F. (2017). The nature of industrial development and the speed of structural change. Structural Change and Economic Dynamics, 42, 26-37.

Russu, C. (2015). Industrial Specialization of the European Union Member Countries. Economic Insights-Trends \& Challenges, 67(2). 63-73.

Saboniene, A. (2009). Lithuanian export competitiveness: comparison with other Baltic States. Engineering Economics, 62(2). 49-57.

Szirmai, A. (2012). Industrialisation as an engine of growth in developing countries, 1950-2005. Structural change and economic dynamics, 23(4). 406-420.

UNIDO, (2017). Competitive Industrial Performance Report 2016, The Industrial Competitiveness of Nations Looking back, forging ahead, Vienna International Centre, UNIDO, Vienna, p. 4.

UNIDO. (2015). Industrial Development Report 2016. The Role of Technology and Innovation in Inclusive and Sustainable Industrial Development. Vienna. 28.

Upadhyaya, S. \& Yeganeh, S. M. (2015). Competitive Industrial Performance Report 2014. Research, statistics and industrial policy branch, Working paper series, 12/2014, UNIDO. 2-8.

Warwick, K. (2013). Industrial Policy: Emerging Issues and New Trends. doi: org/10.1787/5k4869clw0xp-en. 